\title{
THE INTERACTION OF TETANUS TOXIN AND ANTITOXIN
}

\author{
By B. CINADER AND B. WEITZ \\ The Lister Institute of Preventive Medicine, London and Elstree
}

(With 1 Figure in the Text)

\section{CONTENTS}

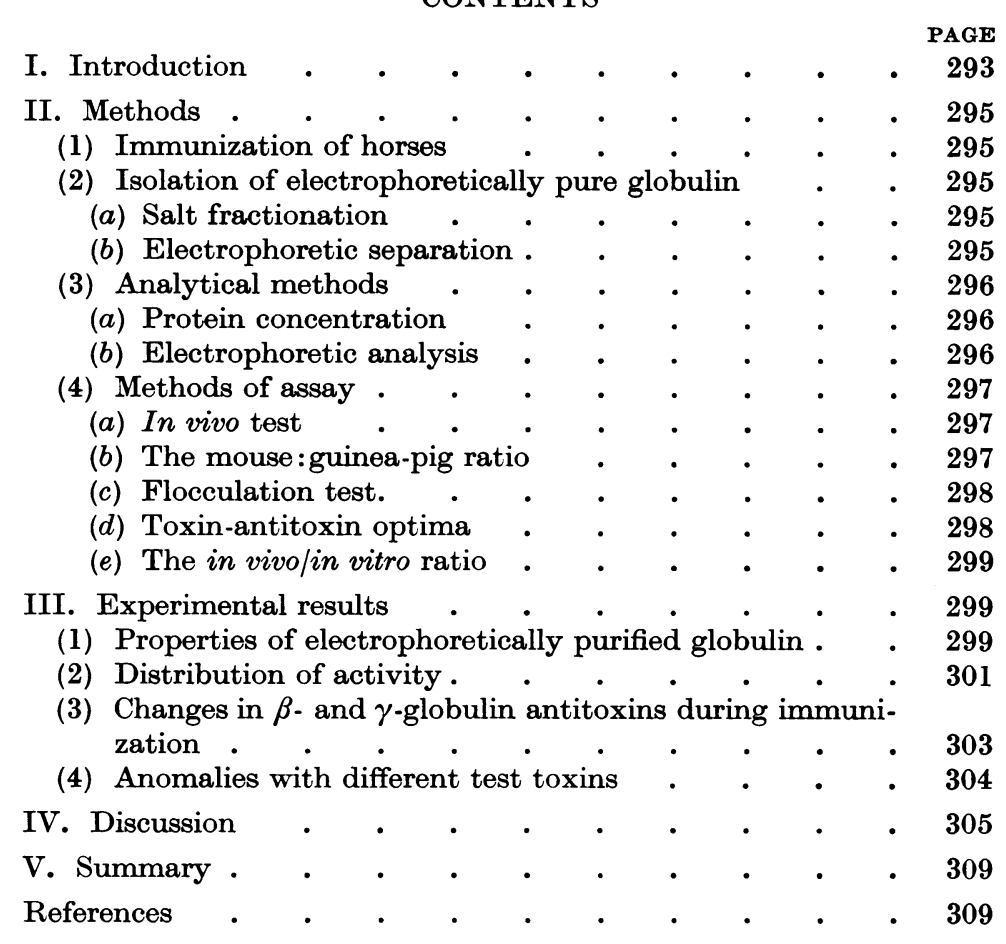

\section{INTRODUCTION}

Evidence for the formation of various different antitoxins against a single toxin has accumulated since Roux criticized Ehrlich's method for determining antitoxins at the beginning of this century. Roux stated that antisera containing large numbers of units of antitoxin were not always the most effective clinically. Cruveilhier (1905) supported this observation. Kraus and his collaborators (Kraus, 1903; Kraus \& Doerr, 1905; Kraus \& Pribram, 1905; Kraus \& Schwoner, 1908; see also Topley \& Wilson, 1946) arrived at similar conclusions and proposed the term avidity to explain the difference between results obtained when antitoxic activity is measured by Ehrlich's method and by the method of injecting toxin and antitoxin separately.

Most of the work on avidity has been carried out with diphtheria toxin and antitoxin. Madsen \& Schmidt (1930) found that mixtures of diphtheria toxin and certain antitoxic sera were neutral when tested by subcutaneous injection into 
guinea-pigs, but lethal when injected by the same route into rabbits. Other sera gave mixtures which were equally harmless to guinea-pigs and rabbits.

Glenny \& Barr (1932) meant by avidity the quality which determines firmness of combination of toxin and antitoxin. They studied the effect of diluting mixtures of toxin and antitoxin, using antitoxins and fractions thereof that had different speeds of flocculation. They measured the dilution ratio, i.e. the ratio of the amount of antitoxin necessary to form a neutral mixture with one $L r$ dose of toxin in a total volume of $2 \mathrm{ml}$., to the amount required to neutralize the same dose of toxin in a total volume of $200 \mathrm{ml}$. Each mixture was tested by injecting volumes of $0.2 \mathrm{ml}$. into the skin of guinea-pigs. The dilution ratio varied from 0.61 to 1.24 for different antitoxic fractions. In vivo/in vitro ratios of the antitoxins and fractions were determined by comparing the antitoxin content, as shown by the Ramon flocculation procedure (Ramon, 1922), with the neutralizing power of sera tested subcutaneously in guinea-pigs. Sera with high in vivo/in vitro ratios gave high dilution ratios, and vice versa, but both ratios were independent of flocculation time. That the dilution ratios and in vivo/in vitro ratios of the fractions from one serum were different suggested that more than one type of antitoxin existed in the whole serum; at any rate in diphtheria antitoxin from the horse.

Kekwick \& Record (1941) applied electrophoretic methods to this problem, and demonstrated that diphtheria antitoxic horse sera contained two types of antitoxin, one associated with the $\gamma$-globulin, the other with the $\beta$-globulin. The two globulins differed in their in vivo/in vitro ratios, in their speeds of flocculation and in the amounts of nitrogen per $L f$ unit, and each of them showed remarkable uniformity in these respects. Kekwick \& Record followed changes in the globulins of the horse during diphtheria immunization and observed that, during the first stages of hyper-immunization, antibodies moved with the $\gamma$-globulin, whereas later most of them moved with the $\beta$-globulin. The flocculation time increased and in vivo/in vitro ratios decreased as immunization progressed. They concluded that the $\gamma$-globulin antibody was the more avid of the two globulins and might be therapeutically more valuable (Kekwick \& Record, 1941; Kekwick, Knight, Macfarlane \& Record, 1941).

The question arises, whether these phenomena are characteristic of diphtheria antitoxin or of antitoxic horse sera in general. The study of other antigen-antibody systems, therefore, appeared of interest and tetanus toxin and antitoxin were chosen for first attention.

Hartley (1927, unpublished, quoted by Llewellyn Smith, 1938) noted qualitative differences between the American and British Standard Tetanus Antitoxin. In subsequent years discrepancies between antitoxic values obtained in different laboratories with the same serum led to an international experiment. Five samples of the same tetanus antitoxin were assayed in five different institutes. The Commission concluded '.. the variations in the results are larger than can be reasonably ascribed to the errors inherent in the methods of assay adopted; they are due to qualitative differences in tetanus toxins and antitoxins...' (Report, 1938). Similar conclusions were drawn by Petrie (1942-4) from results obtained by comparing protective values of tetanus antitoxin sera in mice and in guinea-pigs. 
Dilution tests of tetanus toxin-antitoxin mixtures, published by Glenny, Barr, Ross \& Stevens (1932), showed a qualitative difference between antitoxic fractions, like that obtained with diphtheria antitoxin.

Kekwick (1941) found as much as half of the total activity of tetanus antitoxic sera from a hyperimmune horse in the $\gamma$-globulin fraction. Smith \& Gerlough (1947) fractionated pooled tetanus antitoxic serum and found 5800 units antitoxin/g. protein in $\gamma$-globulin, 8070 units/g. in a T-globulin fraction and 11,500 units/g. in a fraction designated IV.C. 2 which contained mainly $\beta$-globulin.

We describe in this paper the changes occurring during hyperimmunization of horses against tetanus toxin, and the properties of tetanus antitoxin $\gamma$ and $\beta_{2}$ (otherwise designated $\mathrm{T}$ or $\gamma_{1}$ ), with special reference to the in vivo/in vitro ratio, the flocculation time and the extent to which the toxin-antitoxin complex dissociates on dilution. Dissociation was investigated by titrating antitoxin by the $L+$ method in both mice and guinea-pigs thereby obtaining different in vivo dilutions in the different blood volumes in the two animals, or by observing the effect of in vitro dilution of toxin-antitoxin mixtures tested in mice.

\section{METHODS}

\section{(1) Immunization of horses}

The horses Boyer and Myrna were immunized with toxoid from toxin purified by Eaton's method (Eaton \& Gronau, 1938). Each horse was given an initial injection of toxoid made from $47.5,170,380,760,950$, and $1030 L+/ 5$ doses of toxin, respectively on the 60 th, 67 th, 75 th, $82 \mathrm{nd}, 89$ th and 100 th day. On the 89 th day Boyer's serum had reached 195 units $/ \mathrm{ml} .(L+/ 5)$ as measured by mouse protection. Other bleedings were obtained from horses immunized with crude toxoid in the course of the routine preparation of antitoxic sera.

\section{(2) Isolation of electrophoretically pure globulin}

(a) Salt fractionation was carried out by the method of Kekwick \& Record (1941). Serum was precipitated with $18 \mathrm{~g} . / 100 \mathrm{ml}$. sodium sulphate at $37^{\circ} \mathrm{C}$., and the precipitate (PI) was dissolved in phosphate buffer at $\mathrm{pH} 8$ and ionic strength $I=0 \cdot 2$, and re-precipitated with $15 \mathrm{~g}$. $/ 100 \mathrm{ml} . \mathrm{Na}_{2} \mathrm{SO}_{4}$ at $37^{\circ} \mathrm{C}$. The second precipitate (PII) consisted of $\beta$ - and $\gamma$-globulin; the supernatant (SII) contained some albumin and $\alpha$ - and $\beta$-globulin, but no $\gamma$-globulin. The distribution of antitoxic activity and proteins amongst the salt fractions of the serum of horse Affable is shown in Table 1.

(b) Electrophoretic separation. The concentrates obtained by salt fractionation were fractionated electrophoretically. Phosphate buffer $(\mathrm{pH} 8, I=0 \cdot 3)$ was used with protein concentrations of $6-7 \mathrm{~g}$. $/ 100 \mathrm{ml}$. in experiments designed to prepare $\beta$ - and $\gamma$-globulin in fairly large quantities. The time taken for separation was about $20 \mathrm{hr}$., and the initial current was $10 \mathrm{~mA}$., gradually increased to 15 or $20 \mathrm{~mA}$. The $\gamma$-globulin was obtained from the descending side of PII and the $\beta$-globulin usually from the descending side of SII but sometimes from the ascending side of PII. 
Table 1. Salt fractionation of tetanus antitoxic horse serum Affable

\begin{tabular}{|c|c|c|c|c|c|}
\hline & $\begin{array}{l}\text { Vol. } \\
\text { (ml.) }\end{array}$ & $\begin{array}{l}\text { Total units } \\
(L+/ 5)\end{array}$ & $\begin{array}{c}\text { Total } \\
\text { antitoxin } \\
\text { (percentage) }\end{array}$ & $\begin{array}{l}\text { Total protein } \\
\quad\left(\text { vol. } \times n_{s}\right)\end{array}$ & $\begin{array}{l}\% \text { total } \\
\text { protein }\end{array}$ \\
\hline Serum & 500 & $1,175,000$ & 100 & 10 & 100 \\
\hline Supernatant I & 230 & 15,000 & 1 & $1 \cdot 6$ & 16 \\
\hline $\begin{array}{l}\text { Precipitate I (alb., } \alpha, \\
\quad \beta, \gamma)\end{array}$ & 515 & $1,185,000$ & 100 & $7 \cdot 6$ & 76 \\
\hline \multicolumn{6}{|l|}{ Precipitate I } \\
\hline $\begin{array}{l}\text { Supernatant II (alb., } \\
\alpha, \beta)\end{array}$ & 200 & 3,000 & $0 \cdot 3$ & 0.4 & 4 \\
\hline Precipitate II $(\beta, \gamma)$ & 315 & 990,000 & 84 & $5 \cdot 8$ & 58 \\
\hline
\end{tabular}

Units determined in vivo by mouse titration with $L+/ 5$ toxin.

When the precipitate (PII) was used for the preparation of $\gamma$-globulin only, it was dissolved in phosphate buffer $(\mathrm{pH} 8, I=0 \cdot 2), 7 \mathrm{~g} . / 100 \mathrm{ml}$., and was subjected to electrophoretic separation for 12-14 hr. Owing to the boundary anomalies the components did not migrate with the same mobility in the two limbs of the $U$-tube, so that when the cathode side was cut off in a position which gave pure $\gamma$-globulin a mixture of $\beta$ - and $\gamma$-globulin was obtained on the anode side. Occasionally unfractionated serum was treated in a similar way to obtain globulin. The $\beta$-globulin was usually obtained by electrophoretic separation of SII in phosphate buffer ( $\mathrm{pH} 8, I=0 \cdot 2)$ at a protein concentration of about $2 \mathrm{~g}$. $/ 100 \mathrm{ml}$., and at the same time an albumin plus $\alpha$-globulin fraction was obtained from the anode compartment. Since the SII fraction contained $\beta$-globulin as the only immunologically active substance, this fraction was used to study the antitoxic properties of $\beta$-globulin unless in vivo efficacy (see p. 302) was to be investigated, when electrophoretically purified $\beta$-globulin was used.

\section{(3) Analytical methods}

(a) Protein concentration. Protein concentrations were measured throughout with a dipping refractometer in terms of refractive increment. Undiluted samples of serum or of protein fractions were dialysed at constant volume against phosphate buffer ( $\mathrm{pH} 8, I=0 \cdot 2$ ) until ionic equilibrium was attained; this usually involved two changes of 10 vol. of buffer daily for 4 days. The refractions of the buffer $\left(n_{0}\right)$ and of the non-dialysable material $\left(n_{1}\right)$ were measured at $25^{\circ} \mathrm{C}$. with monochromatic light $(\lambda=546 \mathrm{~m} \mu)$.

For the determinations of the protein content of fractions and of the sera from which they were prepared, ten readings were made, five by adjusting the dark field of the dipping refractometer from above, five from below and the mean value taken. The refractive increment of the protein in the solution is $n_{1}-n_{0}=n$, where $n_{1}=$ refraction of the protein solution in buffer and $n_{0}=$ refraction of the buffer; $n_{s}$ is the refractive increment of a whole serum, and $n_{f}$ of a fraction.

(b) Electrophoretic analysis. Electrophoretic measurements were made at $0^{\circ} \mathrm{C}$. in the Tiselius apparatus (Tiselius, 1937; see also Abramson, Moyer \& Gorin, 1942). For the optical observations Philpot's method (1938) was used, the light 
source being a high-pressure mercury arc from which monochromatic light $(\lambda=546 \mathrm{~m} \mu)$ was isolated with a suitable filter. Analytical experiments were carried out in phosphate buffer $(\mathrm{pH} 8, I=0 \cdot 2)$ and the protein concentration was adjusted to $n_{1}-n_{0}=0 \cdot 00400$.

The photographs of electrophoretic patterns were enlarged eight times by projection on to millimetre graph paper. Tracings were extrapolated on the assumption that the individual components, albumin, $\alpha$ - and $\gamma$-globulin, were symmetrical about an axis through assumed Gaussian curves and at right angles to the base-line. The remaining area was allotted to the $\beta$-globulin. The refractive increment contributed by a fraction to the serum is computed from $g=\%$ globulin calculated in this way and $n_{s}=$ refractive increment of the serum.

\section{(4) Methods of assay}

(a) In vivo test. The potency of an antitoxin, in international units as defined in 1928,* was determined by finding the toxin-antitoxin mixture which, when inoculated into groups of five guinea-pigs or mice, caused death of more than half of the animals on the fourth day. The dose was made up in $0.5 \mathrm{ml}$. volumes in gelatin saline for mice and in $5 \cdot 0 \mathrm{ml}$. volumes for guinea-pigs. The mixtures were held for $1 \mathrm{hr}$. at room temperature and were then inoculated intraperitoneally into mice or subcutaneously into guinea-pigs. In all tests preliminary determinations were made of the approximate amount of antitoxin neutralizing the $L+/ 5$ or $L+/ 250$ doses of toxin, the final test was made by inoculating groups of at least five animals with each antitoxin dose, the doses being graded in steps of one-tenth of this neutralizing dose, the series being designed so as to include the neutralizing dose at about its mid-point.

In all titrations on guinea-pigs, the test dose of toxin was $L+/ 5$; in mice, however, in order to measure the dilution ratio, antitoxins or fractions were titrated against two doses of toxin, $L+/ 5$ and $L+/ 250$, and in all experiments control titrations were made against $1 / 5$ or $1 / 250$ units of antitoxin in the form of the Institute laboratory standard antitoxin, which was checked at regular intervals against Standard British antitoxin.

Antitoxin values are expressed in units/ml., qualified by the system in which the ratio of potencies of standard and unknown preparations was measured Thus, unitage determined in vivo is 'units $/ \mathrm{ml} .(L+/ 5)$ ' and 'units $/ \mathrm{ml} .(L+/ 250)$ '.

(b) The mouse:guinea-pig ratio. To determine the in vivo ratios of antitoxin in mice and guinea-pigs (the M:G ratio of Petrie, 1942-4) the test toxin used was a glycerinated preparation, 509, which had previously been used by Petrie. Toxin 509 had reached a stable equilibrium, whereas fresh toxin preparations gave, against the same antitoxin, $M: G$ ratios which increased with time. The use of toxin 509 had the advantage of permitting a direct comparison between the values found in this investigation and Petrie's determinations.

Petrie found that with toxin 509 antitoxin could be titrated within $4 \%$, when a group of five animals was used for each serum dose. The volume of toxin required

* 2 i.u. (1928) are equal to 1 i.u. (1950) and to 1 American unit of tetanus antitoxin. 
for the $L+/ 5$ dose was adjusted so as to give a ratio of one with the Standard British antitoxin. For parallel tests the Institute laboratory standard antitoxin was used.

For convenience dilution ratios and M: G ratios are multiplied by 100 throughout the paper.

(c) Flocculation test. For the test toxin used in these experiments the $L f$ dose was assumed to be equal to the $L+/ 5$ dose. Flocculation values of toxin were measured with the pepsin-digested antitoxin $550 / 551$ chosen as a standard because of its relatively high speed of flocculation (Table 6).

The flocculation mixtures were set up in small thin-walled glass tubes and kept in a glass-fronted water-bath at $49^{\circ} \mathrm{C}$. A black screen was placed behind the tubes which were indirectly illuminated, and observed through the glass wall of the bath. The time taken for the first appearance of floccules, as seen through a magnifying glass, was noted. In all experiments the volume of toxin was kept constant at $1 \mathrm{ml}$. and the volume of antitoxin was varied, the mixture being made up to a final volume of $2 \mathrm{ml}$. with phosphate buffer $(\mathrm{pH} 8, I=0 \cdot 2)$.

The amount of serum that gives optimal flocculation with the $L f$ dose of toxin contains one unit/ml., and unitage so determined is referred to as 'units $/ \mathrm{ml}$. $(L f)^{\prime}$. The time of optimal flocculation is referred to as $K f$.

The toxin solutions used for all the experiments were crude broths from Clostridium tetani strain 279 Tulloch strain 2 (N.C.T.C., no. 5406); and were regularly checked by flocculation against the standards.

(d) Toxin-antitoxin optima. In the tetanus toxin-antitoxin systems investigated three to five distinct flocculation optima were observed in the constant-toxin titrations. Multiple zones have been mentioned by many authors (Scholz, 1924; Abt \& Erber, 1926; Kalic, 1928; O'Brien \& Glenny, 1931), and it has been suggested that the true optimum is that which gives an in vitro titre nearest the in vivo titre. This assumption begs the whole question of the significance of the in vivo/in vitro ratio, for flocculation tests detect the antigen-antibody compound which is least soluble under the conditions of experiment, whereas neutralization tests detect that complex in which most of the toxic groups are no longer free to act. There is no a priori reason why the two tests should give similar titres. The method we finally adopted to identify the true toxin-antitoxin optimum point is that described by Moloney \& Hennessy (1944), which depends on the specific absorption of antitoxin by toxin-antitoxin floccules. Mixtures were prepared of constant amounts of toxin and amounts of antitoxin corresponding to $0 \cdot 67,1$ and 1.5 times the amount contained in the most rapidly flocculating mixture of each zone, and the resulting precipitate treated with excess antitoxin. Since only true toxin-antitoxin floccules take up antitoxin the true optimum mixture is that which absorbs more antibody from added antitoxin. The floccules were allowed to form at $37^{\circ} \mathrm{C}$. from volumes of $25 \mathrm{ml}$. toxin solution to which appropriate volumes of antitoxin varying from 0.3 to $3.6 \mathrm{ml}$. had been added, were centrifuged, washed with physiological saline at $2^{\circ} \mathrm{C}$., and were then added to antitoxin $(7 \mathrm{ml}$. containing 16-18 units $/ \mathrm{ml} .(L+/ 5)$ ) with which they were allowed to remain in contact for $1 \mathrm{hr}$. at room temperature. The mixture was shaken at regular intervals, 
the floccules were centrifuged out, and the in vivo unitage of the antitoxin in the supernatant fluid was determined. This procedure was adopted for all sera and all fractions used in these experiments. One example is shown in Table 2 for an antitoxic serum from horse Keeble.

Table 2. Absorption of antitoxin by floccules from various flocculation optima. Serum Keeble

Vol. of antitoxin* (ml.)

\begin{tabular}{|c|c|c|c|c|}
\hline & $\begin{array}{l}\text { In optimal } \\
\text { flocculation } \\
\text { mixture }\end{array}$ & $\begin{array}{l}\text { In flocculation } \\
\text { mixtures tested }\end{array}$ & $\begin{array}{c}\text { Units of } \\
\text { antitoxin absorbed } \\
\text { by floccules }\end{array}$ & $\begin{array}{l}\text { True toxin- } \\
\text { antitoxin optimum } \\
\text { (ml. antitoxin) }\end{array}$ \\
\hline \multirow{3}{*}{ Serum } & $1 \cdot 25$ & $\left\{\begin{array}{l}1 \cdot 83 \\
1 \cdot 25 \\
0.90\end{array}\right.$ & $\left.\begin{array}{r}70 \\
84 \\
105\end{array}\right\}$ & $1 \cdot 25$ \\
\hline & 0.5 & $\left\{\begin{array}{l}0 \cdot 75 \\
0 \cdot 50 \\
0 \cdot 30\end{array}\right.$ & $\begin{array}{r}102 \\
21 \\
28\end{array}$ & - \\
\hline & $0 \cdot 29$ & $0 \cdot 26$ & 0 & 一 \\
\hline \multirow{2}{*}{$\beta$-Globulin (S II) } & $2 \cdot 4$ & $\left\{\begin{array}{l}3 \cdot 60 \\
2 \cdot 40 \\
1 \cdot 60\end{array}\right.$ & $\left.\begin{array}{r}84 \\
108 \\
70\end{array}\right\}$ & $2 \cdot 4$ \\
\hline & 0.97 & $\left\{\begin{array}{l}1 \cdot 45 \\
0 \cdot 97 \\
0 \cdot 65\end{array}\right.$ & $\begin{array}{r}108 \\
0 \\
0\end{array}$ & - \\
\hline \multirow[b]{2}{*}{$\gamma$-Globulin } & $3 \cdot 73$ & $2 \cdot 80$ & 64 & $3 \cdot 73$ \\
\hline & $1 \cdot 09$ & $\left\{\begin{array}{l}1 \cdot 50 \\
0 \cdot 67\end{array}\right.$ & $\begin{array}{l}14 \\
14\end{array}$ & - \\
\hline
\end{tabular}

* The antitoxin solutions were diluted $(1: 10)$ except the $\gamma$-globulin which was undiluted.

(e) The in vivo/in vitro ratio is units/ml. $(L+/ 5) \div$ units $/ \mathrm{ml}$. $(L f)$. It should be noted that determinations of unitage will depend on the system, consequently the in vivo/in vitro ratios are probably peculiar to the system used in their determination. For example, the ratios for pepsin-digested antitoxin 550/551 when determined with toxins 509 and 711 were 0.41 and 0.63 respectively. When another standard antitoxin (Wellcome Standard LX 319A/9) was employed a toxin which had an $L f$ value of 8 against standard 550/551 had an $L f$ value of 12.

\section{EXPERIMENTAL RESULTS}

\section{(1) Properties of electrophoretically purified globulins}

The $\gamma$-globulin-toxin mixtures appear to dissociate less on dilution (Cinader \& Weitz, 1950) as determined by dilution ratios and M:G ratios (Tables 3, 4).

The in vivo/in vitro ratios and the flocculation times of the two types of antibody are listed (Tables 5 and 6 ). The specificity of the flocculation optima was established by Moloney absorption tests, except for the $\gamma$-globulins from Buck and Myrna.

The values in Table 5 are derived from units $/ \mathrm{ml}$. $(L+/ 5)$. It is of interest to compare them with values from unitages determined from $L+/ 250$ measurements (in brackets). 
Table 3. Dilution ratios $(\times 100)$ of antitoxic sera and fractions

\begin{tabular}{lcrr} 
& Native & \multicolumn{2}{c}{ Globulins } \\
\cline { 3 - 4 } Antitoxic serum & serum & $\gamma$ & $\beta$ \\
Affable & - & 53 & - \\
Boyer, 9 Jan. & 125 & 85 & 140 \\
Keeble & 68 & 55 & 95 \\
Papanek & 106 & 72 & 107 \\
Poobah & 68 & 45 & 113 \\
$\quad$ Pepsin-digested antitoxin 550/551 & 150
\end{tabular}

Table 4. Mouse: guinea-pig ratios $(\times 100)$ of antitoxic sera and fractions

\begin{tabular}{lcrr} 
& Native & \multicolumn{2}{c}{ Globulins } \\
\cline { 3 - 4 } Antitoxic serum & serum & $\gamma$ & $\beta$ \\
Boyer, 9 Jan. & 133 & 71 & 133 \\
Buck & 79 & 73 & 81 \\
Keeble & 87 & 60 & 106 \\
Myrna, 20 Dec. & 80 & 67 & 110 \\
Myrna, 9 Jan. & 86 & 73 & 110 \\
Papanek & 67 & 64 & 100 \\
Pavillion & 72 & 68 & 78 \\
Poobah & 96 & 70 & 82 \\
\multicolumn{2}{c}{ Pepsin-digested antitoxin 550/551 } & 200 \\
Pepsin-digested antitoxin 408 & 86
\end{tabular}

Table 5. In vivo/in vitro ratios of antitoxic sera and fractions

\begin{tabular}{|c|c|c|c|}
\hline \multirow[b]{2}{*}{ Antitoxic serum } & \multirow[b]{2}{*}{ Native serum } & \multicolumn{2}{|c|}{ Globulins } \\
\hline & & $\gamma$ & $\beta$ \\
\hline Affable & $2 \cdot 4$ & $2 \cdot 8$ & - \\
\hline Boyer, 9 Jan. & $1 \cdot 0$ & - & 0.8 \\
\hline Buck & $2 \cdot 3$ & $2 \cdot 7$ & - \\
\hline Keeble & $1 \cdot 5(2 \cdot 2)$ & $2 \cdot 6(4 \cdot 4)$ & $1.2(1.3)$ \\
\hline Myrna, 9 Jan. & 0.9 & $2 \cdot 8$ & $0 \cdot 7$ \\
\hline Papanek & $1 \cdot 1(1 \cdot 2)$ & $2.4(3.3)$ & $1 \cdot 0(1 \cdot 1)$ \\
\hline Poobah & $1.6(2 \cdot 3)$ & $1 \cdot 3(2 \cdot 9)$ & $1.9(1.7)$ \\
\hline
\end{tabular}

Pepsin-digested antitoxin 550/551 $0.76(1.51)$

Units determined in vivo against $L+/ 5$ dose of toxin. Values in brackets are ratios when unit determined in vivo against $L+/ 250$.

The in vivo/in vitro ratio is greater for the $\gamma$ - than for the $\beta$-globulins in all sera except that from Poobah, in which the ratio for $\beta$ - is greater than for the $\gamma$ globulin. Nevertheless, even for this serum the ratio for the $\gamma$-globulin fraction is higher when the unitage in vivo is determined at the $L+/ 250$ level. Antibody in the $\gamma$-globulin fraction has a much shorter flocculation time $(K f)$ than $\beta$-globulin antibody (Table 6). The flocculation times shown relate to mixtures containing $6 L_{f}$ doses of toxin per ml. unless otherwise indicated in brackets. 
Table 6. Kf of antitoxic sera and fractions

\begin{tabular}{|c|c|c|c|}
\hline \multirow[b]{2}{*}{ Antitoxic serum } & \multirow{2}{*}{$\begin{array}{l}\text { Native } \\
\text { serum }\end{array}$} & \multicolumn{2}{|c|}{$\begin{array}{l}K f(\min .)^{*} \\
\text { Globulins }\end{array}$} \\
\hline & & $\gamma$ & $\beta$ \\
\hline Affable & 64 & 40 & - \\
\hline Boyer, 9 Jan. & 326 & - & 660 \\
\hline Buck & 80 & $78(3)$ & - \\
\hline Keeble & 145 & $\begin{array}{r}141(3) \\
69(4 \cdot 2)\end{array}$ & 165 \\
\hline Myrna, 9 Jan. & 360 & $177(3)$ & 397 \\
\hline Papanek & 310 & 59 & 328 \\
\hline Poobah & 490 & 182 & 500 \\
\hline Pepsin-dige & antitoxin & $/ 551$ & \\
\hline
\end{tabular}

* $K f$ was determined with $6 L f$ toxin $/ \mathrm{ml}$. of flocculating mixture unless otherwise stated in brackets.

\section{(2) Distribution of activity}

The amount of $\beta$ - and $\gamma$-globulin is determined from the electrophoretic analysis (Table 7) and the total refractive increment of each serum.

The activity of an antiserum can be computed from the activity, and from the electrophoretically determined amount, of each of its components, and presented as a balance sheet (Table 8).

Table 7. Electrophoretic analysis of some sera

$\begin{array}{lccc} & \text { Keeble } & \text { Papanek } & \text { Poobah } \\ \text { Percentage composition (g.) } & & \\ \text { Albumin } & 19 \cdot 3 & 12.5 & 21 \\ \alpha \text {-Globulin } & 14 \cdot 6 & 13.5 & 14 \cdot 9 \\ \beta \text {-Globulin } & 40 \cdot 9 & 52 \cdot 5 & 37 \cdot 8 \\ \gamma \text {-Globulin } & 25 \cdot 2 & 21 \cdot 6 & 26 \cdot 4\end{array}$

Table 8. Distribution of activity amongst the components of three hyperimmune sera

$\begin{array}{lccc} & \text { Keeble } & \text { Papanek } & \text { Poobah } \\ \gamma \text {-Globulin } & & & \\ n_{s} \times g \times 10^{5} & 444 & 407 & 447 \\ \text { In vivo efficacy } & 1 \cdot 29 & 4 \cdot 09 & 1 \cdot 84 \\ \text { In vitro efficacy } & 0 \cdot 50 & 1 \cdot 69 & 1 \cdot 41 \\ \quad \text { Total units } / \text { ml. }(L+/ 5) & 573 & 1665 & 822 \\ \quad \text { Total units/ml. }(L f) & 222 & 688 & 630 \\ \beta \text {-Globulin } & & & \\ n_{s} \times g \times 10^{5} & 720 & 990 & 640 \\ \text { In vivo efficacy } & 3 \cdot 70 & 4 \cdot 59 & 3 \cdot 11 \\ \text { In vitro efficacy } & 3 \cdot 09 & 4 \cdot 56 & 1 \cdot 63 \\ \text { Total units } / \mathrm{ml} .(L+/ 5) & 2664 & 4544 & 1990 \\ \quad \text { Total units } / \mathrm{ml} .(L f) & 2225 & 4514 & 1043 \\ \text { Serum } & & & \\ \text { Calculated units } / \mathrm{ml} .(L+/ 5) & 3237 & 6209 & 2812 \\ \text { Observed units } / \mathrm{ml} .(L+/ 5) & 3400 & 5500 & 2500 \\ \text { Calculated units } / \mathrm{ml} .(L f) & 2447 & 5202 & 1673 \\ \text { Observed units } / \mathrm{ml} .(L f) & 2330 & 5217 & 1538\end{array}$


The total activity of an electrophoretic component is the product of its activity per unit amount of protein (measured in terms of refractive increment) multiplied by the refractive increment contributed by the fraction to the serum.

The distribution of activity in the various electrophoretic components can be drawn up as follows. Using refractive increment as measure of the protein concentration, the refractive increment for a given fraction is $n_{s} \times g$, where $n_{s}$ is the refractive increment of the whole serum and $g$ is the percentage of the total area of the electrophoretic pattern occupied by that fraction.

The unitage of the fraction in terms of contained protein is given by $a / n_{f}$ or $b / n_{f}$ where $a$ is units $/ \mathrm{ml}$. ( $\left.L+/ 5\right), b$ is units $/ \mathrm{ml}$. $(L f)$, and $n_{f}$ is the refractive increment of the electrophoretically isolated fraction. Since $a$ and $b$ differ, we have named these values as follows: $a /\left(n_{f} \cdot 10^{5}\right)=i n$ vivo efficacy of a fraction, $b /\left(n_{f} \cdot 10^{5}\right)=$ in vitro efficacy of a fraction.

The total activity contributed by a given electrophoretic fraction to the activity of the whole serum then is

$$
\begin{array}{ll}
\text { Total units } / \mathrm{ml} .(L+/ 5) & a g n_{s} / n_{f} \text { (in vivo assay). } \\
\text { Total units } / \mathrm{ml} .(L f) & b g n_{s} / n_{f} \text { (in vitro assay) }
\end{array}
$$

The sera from horses immunized with crude toxoid in the course of routine antitoxin production showed several optima (Table 9); zones of true optima were determined by adsorption tests (Table 2).

Table 9. Comparison of unitage antitoxin determined by (a) in vivo test in mice, and (b) from multiple flocculation optima

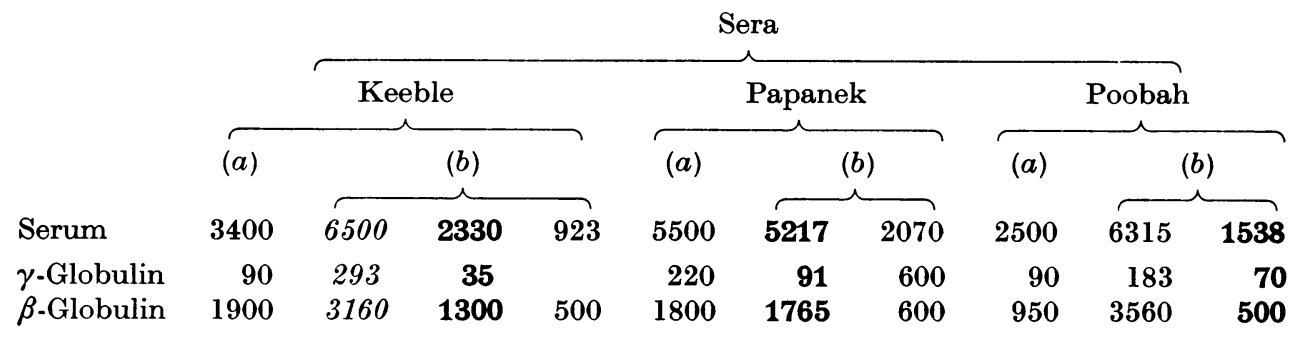

Unitage in heavy type determined from proved toxin-antitoxin optima; unitage in italics determined from 'heat stable' antigen other than toxin-toxoid and its antibody (Moloney \& Hennessy, 1944).

Optima due to the 'heat stable' antigen and its antibody were determined by the method of Moloney \& Hennessy (1944), who found that whereas several optima were observed on flocculation with untreated toxin, only one optimum was found with toxin heated for 15 min. at $63^{\circ} \mathrm{C}$. The $K f$ with $6 L f$ heated toxin 711 with the serum and fractions of Keeble was $435 \mathrm{~min}$. for the serum, $474 \mathrm{~min}$. for $\beta$-globulin and $75 \mathrm{~min}$. for $\gamma$-globulin. That is to say, antibody to an antigen other than the toxin resembles the antitoxin in that the $\gamma$-globulin has the shortest $K f$.

If $i n$ vivo tests are carried out at different levels of dilution, the relative contribution made by each of the two globulins will not be the same because the more 
avid antibody contributes more to the total protective power of a serum at a greater dilution, since its compound with toxin dissociates less.

The units/ml. $(L+/ 5)$ used in the original activity balance sheets differed from those found later when titrations against toxins 509 and 711 were made simultaneously. Since these later values were determined on SII rather than on electrophoretically isolated $\beta$-globulin, the ratio of units $(L+/ 5)$ to units $(L+/ 250)$ was determined and the new distribution of activity was obtained by multiplying the values in the original balance sheets by the appropriate ratios (Table 10). The contribution of $\gamma$-globulin to the antitoxin activity is apparently greater at the $L+/ 250$ level than at the $L+/ 5$ level (cols. 5 and 6). Similarly, when the distribution of activity was determined by measurements in mice and guinea-pigs against toxin 509 (cols. 3 and 4 ) the $\gamma$-globulin protected more effectively in the guinea-pig, presumably because of the higher dilution of toxin-antitoxin complexes in the guinea-pig circulation.

(3) Changes in $\beta$ - and $\gamma$-globulin antitoxins during immunization

Van der Scheer, Wyckoff \& Clarke (1941) studied the serum of a horse by electrophoresis at various stages of hyperimmunization with tetanus toxin. They found an increase in the $\beta_{2}$, or $T$, component, which was associated with an increase in antitoxic unitage, but this increase was not linearly related to the increase in antitoxic activity, that is to say, a change in the proportion of an antibody-bearing electrophoretic component is not a reliable measure of increase in specific titre of the serum.

Table 10. Percentage of total activity of sera contributed by $\gamma$-globulin, determined by various tests

\begin{tabular}{|c|c|c|c|c|c|}
\hline \multirow[b]{3}{*}{ Serum } & \multirow[b]{3}{*}{ In vitro } & \multicolumn{4}{|c|}{ In vivo } \\
\hline & & \multirow{2}{*}{$\begin{array}{c}\text { In the } \\
\text { guinea-pig } \\
\text { (Toxin 509) }\end{array}$} & \multicolumn{3}{|c|}{ In the mouse } \\
\hline & & & (Toxin 509) & $\overbrace{(\operatorname{Toxin} 711)}$ & $(\operatorname{Toxin} 711)^{*}$ \\
\hline Keeble & 9 & 26 & 16 & 18 & 30 \\
\hline Papanek & 13 & 35 & 26 & 27 & 36 \\
\hline Poobah & 38 & 28 & 28 & 29 & 50 \\
\hline
\end{tabular}

The progress of immunization was followed in the horse Boyer by all the methods of assay, using bleedings taken on the 89th, 103rd and 109th days after the beginning of the course of immunization.

In spite of the use of purified toxoid for immunization, the antisera from all the bleedings showed two zones of flocculation. The titre indicated by the false zone increased at a slower rate than the true antitoxin titre. The in vivo/in vitro ratios and avidities of the sera as determined by the dilution and $M: G$ ratios decreased as the titre increased (Table 11). Ultracentrifugal analysis (see Svedberg \& Pedersen, $1940)$ did not reveal any changes; a heavy component $\left(S_{20}=15 \cdot 6\right)$ was present before, and did not increase, during immunization. 
Table 11. Serum from horse Boyer. Changes occurring during immunization

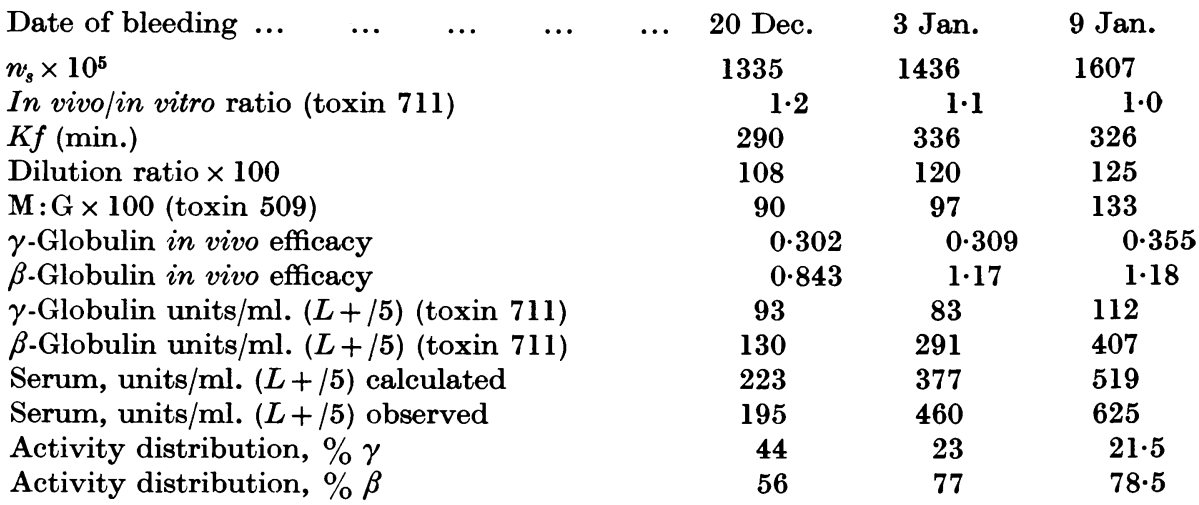

$\beta$ - and $\gamma$-fractions were isolated, their efficacy calculated and the distribution of activity for each serum was computed. Albumin and $\alpha$-globulin fractions were isolated from every serum but were all inactive.

A higher proportion of antitoxic activity was associated with the $\gamma$-globulin in the serum from the earlier bleeding (20 December) of Boyer than in later bleedings (Table 11). The relative contribution of the $\gamma$-globulin antitoxin decreased as the antitoxic titre of the whole serum increased. This suggests that the formation of $\gamma$-globulin antibodies predominated in the early stages of immunization and of the $\beta$-globulin antibodies in the later stages.

\section{(4) Anomalies with different test toxins}

We have so far established that with a given antitoxin the estimates of potency vary with the method of assay, and that with a given horse they vary with the bleeding; these variations are due to the different quantities of $\beta$ - and $\gamma$-globulin antitoxin present in sera from various horses and in different bleedings from the same horse.

Estimates of potency also vary with the toxin used. This is illustrated by the protective value of bleedings of horse Boyer (Table 12) determined with three different toxins. The in vivo/in vitro ratio depended not only on the level of toxin concentration but also on the toxin employed.

Table 12. Influence of toxin preparation and dose on potencies and in vivo/in vitro ratios of sera from horse Boyer

Toxin used for determination

$\left.\begin{array}{l}711 \\ 711^{*} \\ 703 \\ 509 \\ 711^{*} \\ 711 \\ 703\end{array}\right\}$

Date of bleeding

\begin{tabular}{|c|c|c|}
\hline 20 Dec. & 3 Jan. & 9 Jan. \\
\hline 196 & 460 & 625 \\
\hline 180 & 400 & 500 \\
\hline 125 & 350 & 550 \\
\hline 85 & 300 & 400 \\
\hline $1 \cdot 1$ & $1 \cdot 0$ & 0.8 \\
\hline $1 \cdot 2$ & $1 \cdot 1$ & $1 \cdot 0$ \\
\hline $0 \cdot 8$ & $0 \cdot 8$ & 0.9 \\
\hline
\end{tabular}


The ratio of antitoxic values of the three bleedings determined against toxins 509 and 711 differed consistently from 1 (Table 13).

The behaviour of globulin fractions towards these two different toxins is compared in Table 14. The ratio of units $/ \mathrm{ml} .(L+/ 5)$ determined against toxins 509 and 711 is consistently greater for $\beta$ - than for $\gamma$-globulin. The behaviour of the toxin towards the two globulins appears to differ slightly; a relatively smaller amount of $\gamma$-globulin antibody than of $\beta$-globulin antibody neutralized a given dose of toxin 711 than of toxin 509. This is also shown by the percentage activity contributed by the two globulins measured with these toxins (Table 10).

Table 13. The ratio of the antitoxic values of the Boyer series determined with two toxins

$\begin{array}{cc}\text { Date of bleeding } & \text { Ratio: } \\ \text { 20 Dec. } & \text { unitage with toxin } 509 \\ \text { 3 Jan. } & 0.43 \\ \text { 9 Jan. } & 0.65 \\ & 0.64\end{array}$

Table 14. Influence of toxin preparation on results of in vivo assays. Ratio of unitages determined with toxins 509 and 711

$\begin{array}{cccc}\text { Antitoxic serum } & \text { Native serum } & \overbrace{\beta} \text { Globulins } \\ \text { Keeble } & 0 \cdot 76 & 0.95 & \gamma \\ \text { Papanek } & 0 \cdot 71 & 0.73 & 0.82 \\ \text { Poobah } & 0.73 & 0.78 & 0.69 \\ & 0.72\end{array}$

Pepsin-digested antitoxin 550/551 $\quad 0 \cdot 67$

An antitoxin of low avidity may well be less efficient than an avid antitoxin in binding a non-avid toxin, but differences in avidity of antitoxin components cannot account entirely for the behaviour toward different toxins since there is no agreement between the values for similar fractions from different horses (Table 14). Thus, toxin ratio, 0.43 of the serum with the highest content of $\gamma$-globulin (Boyer, 20 December, Table 13) is considerably smaller than that of any pure $\gamma$-globulin obtained from other horses (Table 14) of which the lowest was 0.69. Furthermore, pepsin-digested antitoxin 550/551, which has an exceptionally low avidity (Table 4), resembles $\gamma$-globulin in its behaviour towards the two toxins (Table 14).

\section{DISCUSSION}

In all sera examined antitoxin was associated with both $\gamma$ - and $\beta$-globulin. $\gamma$-globulin antitoxin had a shorter flocculation time than $\beta$-globulin antitoxin and dissociated less on dilution. During immunization the unitage of the $\gamma$ globulin antitoxin rose to a constant value, but that of $\beta$-globulin antitoxin increased later to a still higher value. In successive sera from horse Boyer flocculation time, dilution ratio and $M: G$ ratio increased with the increase in $\beta$-globulin antitoxin.

Petrie (1942-4) found in four series of experiments that the avidity of sera as 
measured by $\mathrm{M}: \mathrm{G}$ ratio increased during immunization. This, in conjunction with the findings presented in this paper, suggests that $\beta$-globulin was formed first during immunization. Petrie does not give details of the dates of injections, but there were long intervals of about 4 weeks between consecutive bleedings, whereas in the present studies the rise of activity and change of avidity was observed over a period of only 10 days. The values we record lie on a curve of steadily increasing titre, whereas after the long intervals in Petrie's experiments each injection of antigen probably stimulated a process of antitoxin formation similar to that occurring over the whole course in the experiments described here; that is, each of the increases observed by Petrie would follow the sequence observed with Boyer but in the first rise less $\gamma$-globulin antitoxin would be produced than in the second, and so on.

The in vivo value and hence the in vivo/in vitro ratio depends not only on the proportions of $\beta$ - and $\gamma$-globulin antitoxin in the serum but also on the qualities of the test toxin.

Tested against toxin 711 successive bleedings from the horse Boyer showed a progressively decreasing in vivo/in vitro ratio (Table 12), corresponding to the increase in $\beta$-globulin antitoxin. Tests with toxin 703 gave in vivo/in vitro ratios increasing with the successive bleedings, nevertheless, as with toxin 711 , the in vivo/in vitro ratio of $\beta$-globulin was smaller than that of intact serum.

The ratio of in vivo units of the series of bleedings measured with two toxins 509 and 711 varied from 0.43 to 0.65 (Table 13 ).

Since the antitoxin assays depend on the qualities of the test toxin, balance sheets calculated from in vivo determination with one toxin disagreed with the in vivo value of the intact serum measured with another toxin.

A comparison of the balance sheets of hyperimmune antitoxins measured with toxins 509 and 711 (Table 10) shows that a smaller part of the activity due to $\gamma$-globulin is consistently measured by toxin 509 than by toxin 711 . However, the variation due to the different interaction of the two globulin fractions with different toxins is too small to account entirely for the discrepancies observed. The presence of two antigenic and toxic components in tetanus toxin has been suggested in the past, but attempts to demonstrate it have failed.

In all hyperimmune sera analysed $10-40 \%$ of the antitoxin was in the $\gamma$ globulin fraction. The contribution of $\gamma$-globulin to the activity of immune sera depends on the methods of measurement. It was less by in vitro tests than by in vivo tests and greater with the guinea-pig as a test animal than with the mouse. $\gamma$-globulin flocculated more rapidly and $\beta$-globulin more slowly than the serum from which they were prepared. This also applied to antigen-antibody systems involving the heat-stable antigenic contaminant. In one instance the 'heatstable' optima of whole serum and fractions were identified and speeds of flocculation measured, and as with the true toxin, $\gamma$-globulin had the shortest time of flocculation.

Tested against an $L+/ 5$ and $L+/ 250$ dose of toxin the respective $i n$ vivo/in vitro values of $\gamma$-globulin were approximately twice and three times that of $\beta$-globulin antitoxin. 
The term avidity as used here refers to the dissociation of antigen-antibody compounds on dilution. Judged by dilution tests in the mouse and by M:G ratios, $\gamma$-globulin was much more avid than $\beta$-globulin (Tables 3 and 4).

Considerably less than $1 / 50$ of the quantity of $\gamma$-globulin neutralizing an $L+/ 5$ dose of toxin was required to neutralize an $L+/ 250$ dose of the same toxin, consequently the dilution ratio of the $\gamma$-globulins was always less than 1 . Superficially this would imply that such fractions dissociated less readily from toxin in dilute than in concentrated mixtures. The explanation of the phenomenon became evident in the study of an enzyme, $\mathrm{Cl}$. welchii lecithinase, and its antibody (Cinader, to be published). Two neutralization curves (ordinate: antitoxin concentration; abscissa: enzyme activity) of two quantities of toxin and varying

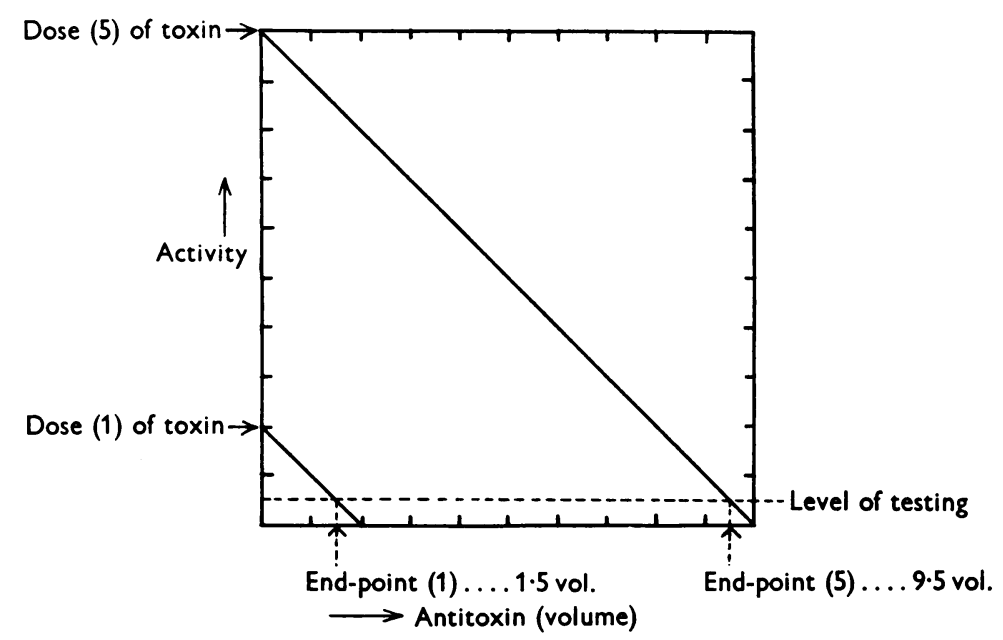

Fig. 1. Diagrammatic representation and determination of the dilution ratio when the toxin-antitoxin complex does not dissociate on dilution.

quantities of antibody were compared. The $L+$ test was represented by a line drawn through the two curves and parallel to the ordinate. The line intersects the two curves at points corresponding to the same absolute activity but different percentage activities. This is shown diagrammatically in Fig. 1. In the absence of dissociation the percentage activity will be higher in the more dilute system and will, therefore, require proportionally less antitoxin. It follows that even a dilution ratio of 1 indicates dissociation. A similar explanation accounts for similar observations on the M:G ratio. This phenomenon has been pointed out by Petrie.

The magnitude of the in vivo/in vitro ratio has often been considered as directly related to avidity. Such a connexion is not self evident. The in vivo/in vitro ratio relates the quantity of antitoxin in a toxin-antitoxin mixture in which a certain indicating dose of toxin is free, to the quantity of antitoxin in the most quickly precipitated toxin-antitoxin compound. When two fractions are compared with one another under strictly controlled conditions the in vivo test measures the same amount of free toxin, whereas the most rapid flocculation used as indicating 
reaction in the in vitro test may indicate different compounds in different flocculating systems. The $L f$ precipitates may, for instance, have a predominant molecular composition of $T A$ for one preparation of antitoxin and of $T A_{2}$ for another, where $T=1$ molecule of antigen, and $A=1$ molecule of antibody. If the toxinantitoxin mixture determined in the in vivo tests contained mainly $T A$ in both these hypothetical cases, the in vivo/in vitro ratio would be 1 and 2 respectively. A similar effect might be produced if one of two preparations contained a proportion of antibody which combined with antigen but did not render it insoluble.

The in vivo/in vitro ratio also depends on the dilution at which the in vivo measurement is carried out, since the in vivo value will change with increasing dilution (Table 5). As Jerne (1951) pointed out, it will also depend on the end-point chosen for the in vivo titration.

The in vivo/in vitro ratio of $\gamma$-globulin from the horse Poobah was smaller than that of $\beta$-globulin antitoxin, when the $L+/ 5$ end-point was used, but larger when $L+/ 250$ was used. This observation shows that a globulin antitoxin which appears to be very avid by the dilution test may, nevertheless, have an abnormally low in vivo/in vitro ratio at a particular level of toxin concentration, and it is quite possible that the relation between the in vivo/in vitro ratios for $\beta$ - and $\gamma$-globulin antitoxins might be reversed by testing against an even larger dose of toxin (e.g. $5 L+$ ) since the ratio would decrease for the $\gamma$-globulin antitoxin and decrease less or remain constant for the $\beta$-globulin antitoxin. Nevertheless, though the in vivo/in vitro ratio for Poobah $\gamma$-globulin antitoxin is not an indication of avidity, the $\beta$-globulin of this preparation, which had a particularly high in vivo/in vitro ratio, is very avid by $M: G$ tests when compared with the other globulin preparations (Table 4).

Thus, $\gamma$-globulin antitoxins appear to be more avid than $\beta$-globulin antitoxins, while pepsin-digested antitoxin seems to behave like a $\beta$-globulin antitoxin except for its $K f$ which resembles that of $\gamma$-globulin antitoxin.

Only one pepsin-digested antitoxin (550/551) was studied in some detail; in comparison with $\beta$-globulins it showed a low in vivo/in vitro value, a relatively high speed of flocculation and an exceptionally low avidity as judged by dilution tests and by $M: G$ ratios; other pepsin-digested antitoxins, however, resembled in their $\mathrm{M}: \mathrm{G}$ ratio the more avid of the $\beta$-globulin antitoxins (Table 4).

The avidity of an antitoxin need not necessarily run parallel to its therapeutic value. An antibody which combines firmly with its antigen has, presumably, a better chance of competing for the antigen with tissue elements than one combining less firmly, but the therapeutic value will ultimately be determined by the relative abilities of the antibodies to pass any barrier between the blood stream and the site of action, and by the rate at which the antibodies are destroyed. This question is the subject of further experimental investigation.

It remains to be noted that the recent investigation of Levine (1952) on the distribution of diphtheria and tetanus antitoxic activities in horse sera resulted in conclusions which might in general indicate that there is no substantial difference between $\beta$ - and $\gamma$-globulins; they do not necessarily contradict our findings. Levine's results were obtained with heated preparations of serum fractions 
prepared solely by precipitations with ammonium sulphate; none of the fractions were electrophoretically pure.

The relative behaviour of $\beta$ - and $\gamma$-globulin antitoxins observed here agrees with that described by Kekwick \& Record (1941) for the diphtheria toxin-antitoxin system both in speed of flocculation and, with one exception, in the in vivo/in vitro ratio.

\section{SUMMARY}

Tetanus antitoxic horse sera were fractionated with sodium sulphate and by electrophoretic separation. The activity of the native serum and of fractions was determined in vivo in the mouse and guinea-pig and in vitro by the flocculation method. All the sera and fractions showed several zones of flocculation. The flocculation optimum corresponding to the toxin-antitoxin complex was selected by absorption of antitoxin to the floccules. The distribution of activity amongst the electrophoretic components of the native serum was computed from electrophoretic analysis, refractive increment measurements and assays of the activity of the electrophoretically pure fractions.

In all the sera examined the antitoxin was associated with both $\beta$ - and $\gamma$ globulin. The $\gamma$-globulin antitoxin had a shorter flocculation time and a higher in vivo/in vitro ratio than $\beta$-globulin. The in vivo/in vitro ratio of $\gamma$-globulin was two to three times that of $\beta$-globulin antitoxin, its exact value depending on the toxin concentration against which the antitoxin was measured. The avidity of $\gamma$-globulin antitoxin was greater than that of $\beta$-globulin antitoxin judged by two independent 'dilution' tests, namely a comparison of the mouse unitage using two concentrations of toxin and a comparison of the values obtained with one concentration of toxin in the mouse and in the guinea-pig. The in vivo values of the various antitoxins varied with the toxin employed in the test.

During the first course of immunization in a horse the $\gamma$-globulin antitoxin rose to a constant value; $\beta$-globulin antitoxin increased to a still higher value later in the course. The avidity of the serum, as measured by the two 'dilution' ratios, also increased during immunization.

Thanks are due to Dr R. A. Kekwick for suggesting this investigation and for valuable discussions, and to Dr J. Keppie for the immunization of the horses and for animal experiments in the exploratory stages of the investigation.

\section{REFERENCES}

Abramson, H. A., Moyer, L. S. \& Gorin, M. H. (1942). Electrophoresis of Proteins. New York: Reinhold Publishing Corporation.

Aвt, G. \& Erber, B. (1926). Sur le titrage des antitoxines et des toxines tétaniques par la floculation. Ann. Inst. Pasteur, 40, 659.

Cinader, B. \& WeITz, B. (1950). Beta and gamma-globulin tetanus antitoxin of the hyperimmune horse. Nature, Lond., 166, 785.

Crovemhier, L. (1905). De la valeur thérapeutique de l'antitoxine dans le sérum antidiphthérique. Ann. Inst. Pasteur, 19, 249.

Eaton, M. D. \& Gronad,A. (1938). Comparative studies on the purification of tetanus and diphtheria toxins. J. Bact. 36, 423.

J. Hygiene 
Glenny, A. T. (1931). Active immunization with toxins. A System of Bacteriology in Relation to Medicine, 6, 106. London: H.M. Stationery Office.

GlenNy, A. T. \& BARR, M. (1932). The 'dilution ratio' of diphtheria antitoxin as a measure of avidity. J. Path. Bact. 35, 91.

Glenny, A. T., Barr, M., Ross, H. E. \& Stevens, M. F. (1932). The influence of avidity upon the standardization of antitoxins. J. Path. Bact. 35, 495.

Jerne, N. K. (1951). A study of avidity. Acta path. microbiol. scand. (Suppl. LxxxviI).

Kalic, D. Z. (1928). Floculation non-spécifique du sérum antitétanique. C.R. Soc. Biol., Paris, 98, 649.

Kekwick, R. A. (1941). The constitution of some antitoxic horse sera. Chem. \& Ind. 60, 486.

Kekwick, R. A., Knight, B. C. J. G., Macfarlane, M. G. \& Record, B. R. (1941). Composition of diphtheria antitoxic sera. Lancet, i, 571.

KEKwICK, R. A. \& ReCORD, B. R. (1941). Some physical properties of diphtheria antitoxic horse sera. Brit. J. exp. Path. 22, 29.

KraUS, R. (1903). Ueber ein akut wirkendes Bakterientoxin. Zbl. Bakt. (1. Abt. Orig.), 34, 488.

KraUs, R. \& Doerr, R. (1905). Die experimentelle Grundlage einer antitoxischen Therapie der bazillären Dysenterie. Z. Hyg. InfektKr. 55, 1.

KraUS, R. \& Pribram, E. (1905). Ueber Choleravibrionen und andere pathogene Vibrionen. Ueber die Beziehung der Vibrionen El Tor zu dem Choleravibrio. Zbl. Bakt. (1. Abt. Orig.), 41, 15, 155.

Kraus, R. \& Schwoner, J. (1908). Ueber Beziehungen des Antitoxingehaltes des Diphtherieserums zu dessen Heilwert. Ueber Avidität der Antitoxine. Zbl. Bakt. (1. Abt. Orig.), 47, 124.

Levine, L. (1952). The antitoxic activity and gamma globulin distribution in fractionated diphtheria and tetanus antitoxin of equine origin. Brit. J. exp. Path. 32, 190.

Madsen, T. \& Schmidt, S. (1930). Die Reaktionsgeschwindigkeit zwischen Diphtherietoxin und Antitoxin und ihre Bedeutung für die Heilkraft des antidiphtherischen Serums. Z. ImmunForsch. 65, 357.

Moloney, P. J. \& Hennessy, J. N. (1944). Titration of tetanal toxins and toxoids by flocculation. J. Immunol. 48, 345.

O'Brien, R. A. \& Glenny, A. T. (1931). Production of Antitoxin for Therapeutic Purposes. $A$ System of Bacteriology, 3, 353. London: H.M. Stationery Office.

Petrie, G. F. (1942-4). Observations on the variable interactions of tetanus toxins and antitoxins. Bull. Hlth Org. L. o. N. 10, 113.

Pнштот, J. St L. (1938). Direct photography of ultracentrifuge sedimentation curves. Nature, Lond., 141, 283.

Ramon, G. (1922). Floculation dans un mélange neutre de toxine-antitoxine diphthériques. C.R. Soc. Biol., Paris, 86, 661.

Report on the Meeting of Serologists of the Permanent Commission on Biological Standardisation. (1938). Bull. Hlth Org. L. o. N. 7, 683.

Scholz, W. (1924). Nachweis und Austitrierung antitoxischer Sera (insbesondere des Tetanus Antitoxins) im Reagenzglas. Zbl. Bakt. (1. Abt. Orig.), 92, 434.

Smith, E. L. \& Gerlough, T. D. (1947). The isolation and properties of the proteins associated with tetanus antitoxic activity in equine plasma. J. biol. Chem. 167, 679 .

Smith, M. Llewellyn (1938). The standardisation of tetanus antitoxin: factors influencing the assay. Bull. Hlth Org. L. o. N. 7, 739.

Svedberg, T. \& Pedersen, K. O. (1940). The Ultracentrifuge. Oxford: Clarendon Press.

Tiselius, A. (1937). CLXXXII. Electrophoresis of serum globulin. II. Electrophoretic analysis of normal and immune sera. Biochem. $J .31,1464$.

Topley \& Wilson's Principles of Bacteriology and Immunity (1946), Revised by G. S. Wilson \& A. A. Miles, 3rd edition. London: Edward Arnold and Co.

VAN Der Scheer, J., Wyckoff, R. W. G. \& Clarke, F. H. (1941). The electrophoretic analysis of tetanal antitoxic horse-sera. J. Immunol. 40, 173. 